\title{
KRAS and EGFR mutations coexisting in lung adenocarcinoma
}

\author{
Vitor Sousa ${ }^{1,2,3,4^{*}}$, Ana Alarcão ${ }^{1,2}$, Patricia Couceiro ${ }^{1,2}$, Maria R Silva ${ }^{1,3}$, Maria J d'Aguiar ${ }^{1}$, Lia Teixeira', \\ Lina Carvalho 1,2,3,4 \\ From 16th International Charles Heidelberger Symposium on Cancer Research \\ Coimbra, Portugal. 26-28 September 2010
}

Lung adenocarcinoma represents about $42 \%$ and $28 \%$ of NSCLC in women and men. Adenocarcinomas incidence is still rising being the most frequent type of NSCLC diagnosed in USA. Both EGFR and KRAS gene mutations can contribute to the development of NSCLC, namely adenocarcinomas. EGFR and KRAS mutations are considered by some authors as mutually exclusive explained by the fact that KRAS-MAPK pathway is one of the downstream signalling pathways of EGFR. Lung cancers with KRAS mutations are resistant to EGFR tyrosine kinase inhibitors.

Sections of the adenocarcinoma of the lung, formalinfixed paraffin-embedded tissues (FFPE), were selected to analyze mutations in EGFR exons 19 and 21 and KRAS - codons 12 and 13 by DNA extraction for polymerase chain reaction (PCR). Exon 19 was studied by fragment analysis and exon 21, codons 12 and 13 were studied by direct sequencing. The analysis of FISH results was done by Cappuzzo's score to EGFR gene. Determination of EGFR protein expression was done by immunohistochemistry (IHC) (Zymed Laboratories).

The authors present a rare case with synchronous EGFR and KRAS mutations. The patient is a 77 years old, male with a central $3 \mathrm{~cm}$ mixed adenocarcinoma. The tumor showed EGFR protein overexpression identified by IHC and chromosome 7 high polyssomy by FISH.

The authors call attention to the fact that although EGFR and KRAS mutations are almost always mutually exclusive in some cases they may coexist in the same neoplasia.

\footnotetext{
* Correspondence: vitorsousa77@netcabo.pt

${ }^{1}$ Instituto de Anatomia Patológica, Faculdade de Medicina da Universidade de Coimbra, Coimbra, Portugal

Full list of author information is available at the end of the article
}

Author details

${ }^{1}$ Instituto de Anatomia Patológica, Faculdade de Medicina da Universidade de Coimbra, Coimbra, Portugal. ${ }^{2}$ Centro de Investigação em Meio Ambiente, Genética e Oncobiologia (CIMAGO), Coimbra, Portugal. ${ }^{3}$ Centro de Pneumologia, Faculdade de Medicina da Universidade de Coimbra, Coimbra, Portugal. ${ }^{4}$ Serviço de Anatomia Patológica dos Hospitais da Universidade de Coimbra, Coimbra, Portugal.

Published: 24 September 2010

\section{doi:}

Cite this article as: Sousa et al:: KRAS and EGFR mutations coexisting in lung adenocarcinoma. BMC Proceedings 2010 4(Suppl 2):P57.
Submit your next manuscript to BioMed Central and take full advantage of:

- Convenient online submission

- Thorough peer review

- No space constraints or color figure charges

- Immediate publication on acceptance

- Inclusion in PubMed, CAS, Scopus and Google Scholar

- Research which is freely available for redistribution

Submit your manuscript at www.biomedcentral.com/submit
C Biomed Central 